\title{
Identification of cells secreting a thymostimulin-like substance and examination of some histoenzymatic pathways in aging avian primary lymphatic organs: II. Bursa of Fabricius
}

\author{
A.M. Mazzone, M. Aita, F. Gabrielli, E. Moriconi, D. De Orsi
}

Department of Human Physiology and Pharmacology "Vittorio Erspamer", Faculty of Medicine, University

"La Sapienza", Roma, Italy

(C)2003, European Journal of Histochemistry

The Bursa of Fabricius of 15 day, 1-, 3-, and 6 month-old adult chickens (White Leghorn strain) were studied by histological and histochemical staining, histoenzymatic reactions (LDH, SDH, $\alpha$-GPDH, NAD, NADPH, $\mathrm{Ca}^{++}$-dependent ATP-ase, $\mathrm{pH}$ 8.5) and by anti-thymostimulin immunoreaction. Positive reactions for mucopolysaccharides and enzymatic activities were located in the epithelia of the follicles, i.e. in follicleassociated-epithelium (FAE), inter-follicle-epithelium (IFE) and in different epithelial compartments of cortical and medullary zones. Positive reaction for thymostimulin-like (TSlike) substance was restricted to FAE cells and weakly to the basal lamina of IFE. In 6-month-old chickens, the FAE cells disappeared; the phenomenon of bursal regression was evident, although not all the follicles were involved. In the few still normal follicles, the good reactivity to the enzymes tested suggests that residual physiological activity is still present, even if reduced.

Key words: Bursa of Fabricius, avian lymphatic organs, aging, thymostimulin, histoenzymology

Correspondence: M. Aita, Department of Human Physiology and Pharmacology "Vittorio Erspamer", Faculty of Medicine, University "La Sapienza", Roma, Italy. Phone: international +39.06.49910734. E-mail: mariangela.aita@uniroma1.it

Paper accepted on April 16, 2003

European Journal of Histochemistry

2003; vol. 47 issue 4 [Oct-Dec]: 325-338
I $t$ is well established that the Bursa of Fabricius (Fabricius Hieronimus, 1621) is a primary lym- phoid organ peculiar to birds. The bursa is responsible for the maturation and differentiation of B-lymphocytes to produce humoral immunological responses. The other primary lymphoid organ, the thymus, instead, is responsible for the maturation and differentiation of T-lymphocytes, leading to cellular immunological responses (Dent and Good, 1965; Schaffner et al., 1974a; Le Douarin et al., 1984).

The structure of the bursa has been described both during the ontogenetic period (Jolly, 191la, 1914; Cordier, 1969; Edwards et al., 1975; Le Douarin et al., 1975; Le Douarin et al., 1976; Le Douarin et al., 1984; Ritter and Lebacq, 1977) and during the posthatching period up to its involution (Jolly, 1911b,1914; Mc Connachie and Ruth, 1973; Glick, 1974, 1983; Bellamy and Mohamed, 1982; Davenport and Allen, 1985).

Since the discovery that the bursa was implicated in the differentiation of B-lymphocytes for humoral immunity (Chang et al., 1955; Glick et al., 1956; Papermaster and Good, 1962; Peterson and Good, 1965), attention was focused, on the one hand, on lymphoid cell populations (Ackermann and Knouff, 1959; Ackermann, 1962; Woods and Linna, 1965; Cooper et al., 1966; Toivanen et al., 1972 a,b; Toivanen et al., 1974; Back et al., 1973; Grossi et al., 1974; Grossi et al., 1976; Glick, 1974, 1983, 1995; Glick et al., 1975; Eerola et al., 1982; Brand et al., 1983; Pink et al., 1985; Lassila, 1989; Nowak et al., 1990; Motyka and Reynolds, 1991; Petrini et al., 1991; Paramithiotis and Ratcliffe, 1993, 1994 a,b, 1996; Reynaud and Weill, 1993; Masteller and Thompson, 1994; Masteller et al., 1995; Paramithiotis et al., 1995; Obranovich and Boyd, 1996; Funk and Thompson, 1996) and, on the other hand, on the epithelial stroma providing the bursal microenvironment within which B-cell maturation and differentiation occurs. 
The bursal microenvironment is constituted by the epithelium covering the bursal plicae, and is characterized by the follicle-associated-epithelium (FAE) covering the follicles, the inter-follicleepithelium (IFE) located between the follicles, the epithelial cell line separating the cortex from the medulla, and the reticular-epithelial cells and secretory-dendritic cells in the medulla (Frazier, 1974; Olah and Glick, 1981, 1987, 1992, 1995; Glick, 1983, 1991, 1994; Lupetti et al., 1983; Lupetti et al., 1990; Houssaint et al., 1986; Eerola et al., 1987; Betti, 1989; Boyd et al., 1990; Wilson and Boyd, 1990; Dolfi et al., 1990; Ciriaco et al., 1994; Davenport and Allen, 1995).

In addition to the its role as primary lymphoid organ for B-cell differentiation, the Bursa of Fabricius functions as a peripheral lymphoid organ (Sorvari and Sorvari,1977; Eerola et al., 1987), as exemplified by the fact that the FAE has phagocytic activity. When various molecular and microbial materials were applied to the anal lips and transported into the bursal lumen, they were phagocytosed by FAE and transferred to the medulla (Bockman and Cooper, 1973; Schaffner et al., 1974; Schaffner and Hess, 1974; Sorvari et al., 1975; Sorvari and Sorvari, 1977; Naukkarinen and Sorvari, 1980; Ekino et al., 1985) thus inducing an antibody response (Eerola et al., 1987).

Furthermore, it has been suggested that the bursa is an endocrine gland (Freeman, 1971), because in the grafting of portions of the bursa enclosed in cell-impermeable Millipore chambers into bursectomized chicks restored their capacity to produce antibodies (St.Pierre and Ackermann, 1965). Later on, a tripeptide hormone isolated from extracts of the Bursa of Fabricius and named bursopoietin or bursin, induced early B-cell differentiation (Brand et al., 1976; Audhya et al., 1991; Audhya et al., 1986).

Anti-bursin serum was found to be localized in the dendritic reticular cells within the follicle, in the epithelial cells between the cortex and medulla and in the basal layer of IFE. FAE and IFE cells were devoid of anti-bursin immunoreaction (Viamontes et al., 1989). Otsubo et al. (2001) found that the FAE-supporting cells were also positive.

It has been reported that somatotropin-releaseinhibiting hormone (SRIH) is contained in cells of the medullary zone of bursal follicles (Aguila et al., 1991), in which prolactin (PRL) receptors are located (Di Carlo et al., 1996).
Lechner et al., (2001) showed that the chicken bursa and thymus possessed all enzymes and cofactors required for glucocorticoid production.

Experiments suggested that bursal development is under hypophyseal control; in fact, in early hypophysectomized (partially decerebrated) chick embryos, the bursa was underdeveloped, with a reduction in the number of follicles and lymphocytes (Jankovic et al., 1981; Mastrolia et al., 1986; Mastrolia et al 1992) and the FAE and IFE cells were undifferentiated (Romano et al., 1996). This picture was partially restored by hypophyseal grafts in the decerebrated embryos (Mastrolia et al., 1987; Romano et al., 1996).

Growth and thyroid hormones were also effective in reconstituting the bursal growth in hypophysectomized domestic fowl (Scanes et al., 1986; Marsh and Scanes, 1994).

We are interested in studying thymostimulin (TS), a thymic factor extracted from calf thymus and composed of a family of polypeptides with molecular weights below 12,000 (Falchetti et al., 1977). TS is able to increase some immunological functions in experimental (D'Agostaro et al., 1980; Shoam and Eshe, 1980; Shoam et al., 1980; Falchetti et al., 1981; Falchetti et al.,1982) and clinical (Aiuti et al., 1979; Davies and Levinsky, 1982; Lin et al., 1987; Touraine and Sanhadjik, 1992) studies.

Using an anti-TS rabbit serum, we localized TS in the thymic reticulo-epithelial cells of the sub-capsular, cortical, medullary zones and in the external sheath of Hassall's corpuscles of calves (Aita et al., 1981; Aita et al., 1984), rats, and mice (Aita et al., 1986), pigs, lambs, rabbits and guinea-pigs (Aita et al., 1989), humans (Aita and Amantea, 1991) and chicks (Aita et al. 1995). Preliminary results revealed the presence of thymostimulin-like substance also in the Bursa of Fabricius of chicken embryos (Aita et al. 1989; Aita et al., 1992; Aita and Mastrolia, 1991). The aim of this study was to determine which type of cell contained TS-like substance and to test some enzymatic pathways and the eventual changes during the aging period.

\section{Materials and Methods}

\section{Bursal specimens}

White Leghorn chickens (Gallus gallus domesticus) aged 15 days 1,3 and 6 months were used. 
Bursae were removed under anaesthesia (Farmotal, Farmitalia, Italy) and fixed in Bouin's liquid for 24 hours at room temperature, dehydrated and embedded in paraffin wax.

Serial sections of $5 \mu \mathrm{m}$ thickness were stained with haematoxylin-eosin, Azan-Mallory, alcian blue, and periodic acid-Schiff (PAS) (Pearse, 1972), for histological and histochemical evaluation. Other sections were incubated with anti-TS for immunostaining.

Other bursae, taken from chickens of the same age, were snap frozen by $\mathrm{CO}_{2}$ and stored at $-20^{\circ} ; 5$ $\mu \mathrm{m}$ thick cryostat sections were picked up on slides, air-dried for at least $30 \mathrm{~min}$ and used for the histoenzymatic reactions.

\section{Anti-thymostimulin immunoreaction}

The preparation and properties of rabbit antibovine TS (TP 1 Serono-R) serum were previously reported (Aita et al., 1981). Briefly, hybrid rabbits were immunized with several intramuscular injections of $1 \mathrm{~mL}$ of calf TS $(10 \mathrm{mg} / \mathrm{mL})$ and emulsified in $1 \mathrm{~mL}$ of complete Freund's adjuvant. Serum specimens were collected from rabbits before their immunization to constitute a pre-immune serum.

Antibody titres of rabbit anti-TS total serum or purified IgG were tested after extensive absorption with calf liver and spleen tissue powders or with liver, spleen and thymus cells, by immunoelectrophoresis. Total serum or purified IgG were also tested against other thymic hormonal factors or sera of mammals and humans, using the double diffusion technique on agar-gel.

Moreover, the absorption of the total serum with TS powder (TPI Serono-R) to saturate the antibody was performed subsequently. The five $\mu \mathrm{m}$-sections, after dewaxing, dehydration in absolute ethanol and blocking of endogenous peroxidase with $1.65 \%$ hydrogen peroxide in methanol for 20 min, were subjected to the indirect peroxidase-antiperoxidase (PAP) method (Sternberger et al. 1970), overnight at $4^{\circ} \mathrm{C}$, using rabbit anti-calf TS serum (dilution 1:100). The succeeding steps were performed by an Ortho Diagnostic Kit as previously reported (Aita et al., 1989a). The immuno-reaction was revealed by 3-amino-9-ethyl-carbazole (EAC) in N-dimethyl formamide in sodium acetate buffer, pH 5.0 (Ortho Diagnostic System).

The sections were not counterstained. For negative-immunoreaction controls, sections of bursae were treated with rabbit pre-immune or absorbed serum instead of the specific anti-serum. Calf, human or chicken thymus was used as a positive control (Aita et al., 1984; Aita et al., 1995; Aita and Amantea, 1991).

\section{Histoenzymatic reactions}

Succinate dehydrogenase (SDH; EC 1.3.99.1) was identified by the NBT method of Nachlas et al., (1957). The method of Verne et al., (1961) was used for localization of lactate dehydrogenase (LDH; EC 1.1.1.27). NADH (EC 1.6.99.3) and NADPH (EC 1.6.99.1) diaphorase were revealed by the procedure reported by Scarpelli et al., (1958). $\mathrm{Ca}^{++}$ATP-ase (EC 3.6.1.3) was identified at $\mathrm{pH} 8.5$ by the method of Wegmann and Bankowski (1960). Mitochondrial $\alpha$-glycero-phosphate dehydrogenase ( $\alpha$-GPDH; EC 1.1.1.8) activity was identified by the method reported by Pearse (1972).

Sodium glycerophosphate, sodium succinate, sodium lactate and nitro-blue tetrazolium were purchased from Sigma (Sigma Chemical Co., St. Louis MO); sodium NADH, sodium NADPH and sodium ATP were purchased from Boehringer Mannheim $\mathrm{GmbH}$.

As negative control, the specific substrates were not added to the incubating media.

\section{Results}

\section{Histological and histochemical appearance}

Histological examination of 15 day- and 1month-old chickens on haematoxilin-eosin, AzanMallory, alcian blue and periodic acid-Schiff (PAS) stained slides revealed a well-formed follicle with the subdivision on cortex and medulla separated by a thin monostratified epithelial line whose basal Iamina was continuous with that of the epithelial cells of the IFE. The apical part of the follicle, instead, was covered by the FAE which was in contact with the medullary zone.

The Azan-Mallory stain revealed thin collagenous fibres around the cortex and between the cortex and medulla, where capillaries, likely in the cortex, were well pictured (Figure 1-a).

The thickness of the cortex and medulla was almost equal, and the two zones were occupied by lymphoid cells. Some star-shaped epithelial-like cells were visible in the medulla.

The luminal surface of the plical epithelium was 


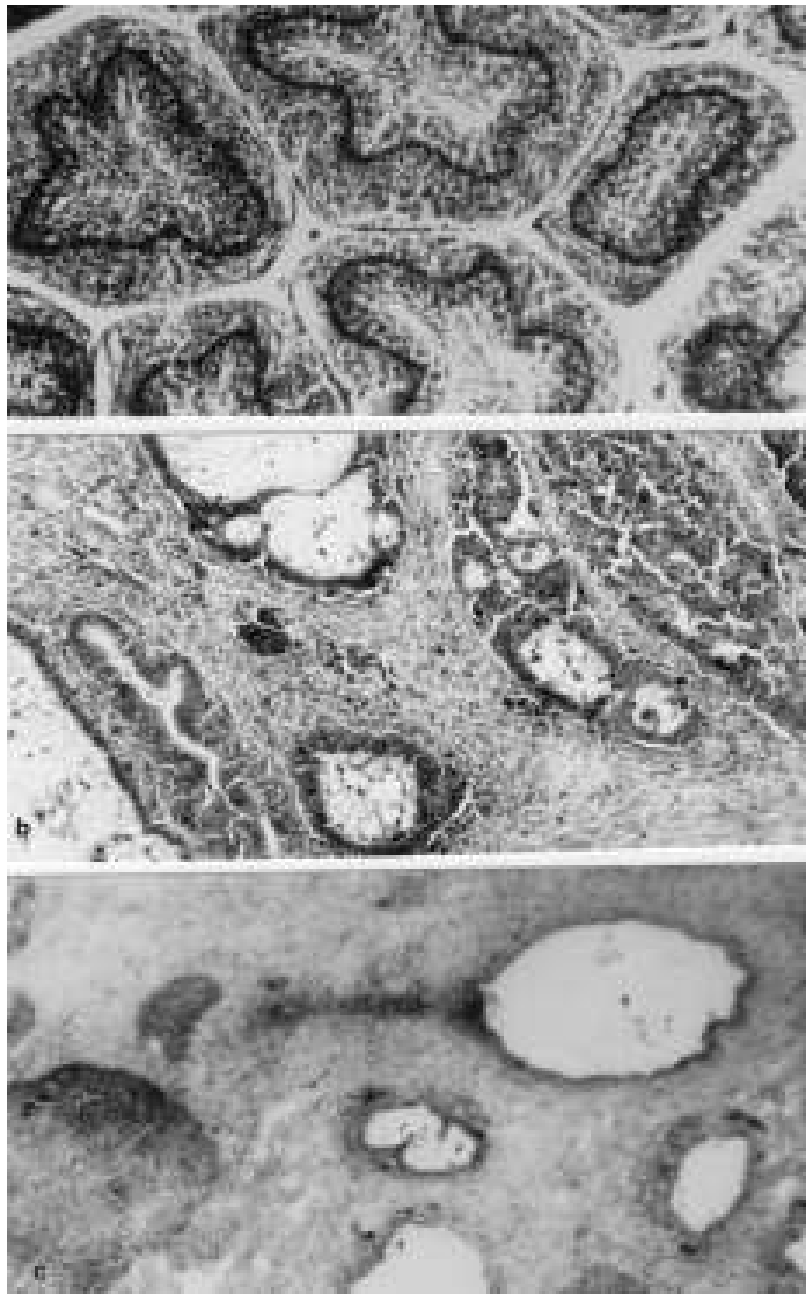

Figure 1. Histological stains: a, 3 month-old chicken. AzanMallory. The line between cortex and medulla is very evident. 25x, b, and c, 6 month-old chicken. Haematoxylin-eosin. Different degrees of involution: $b$, degeneration of medullary zone of follicles. c, the medullary zones are replaced by cysts covered by epithelial cells. $25 x$.

covered by a thin coat of material positive for the PAS and alcian blue reactions.

In the bursae of 3-month-old chickens, the follicles, compressed among them, completely filled the plicae, and showed a polyhedral contour; consequently, the epithelial line between the cortex and medulla took a star-like form (Figure 1-a). In some lateral follicles, the FAE was visible, but its cells were less numerous and evident. The cortex was composed of more numerous lymphocytes than was the medulla, where some epithelial-like cells were visible.

In the bursae of 6-month-old chickens, the phenomenon of regression was well evident; however, it did not simultaneously involve all the follicles. In fact, some follicles had a normal appearance whereas others presented a loss of medullary lymphocytes. The epithelial-like cells secreted neutral and acid polysaccharides, stained by the alcian and PAS reactions.

In other follicles, only a reduced cortex was present and the space of the medulla was filled by alcian blue- and PAS-positive hyaline material.

In the regressed follicles, the epithelial line between cortex and medulla was missing. The plical epithelium was constituted only by IFE and was folded up and detached from the residual follicles (Figure $1-b, c$ ).

\section{Anti-thymostimulin reaction}

In the investigated bursae of 15 day-, 1- and 3month-old chickens, the FAE was strongly immunoreactive to the anti-TS serum (Figure $2-a, b, c$ ). In particular, the TS-like factor was located in the cytoplasm of FAE cells. On the contrary, the cells of the IFE were negative. The basal lamina of the IFE and the epithelial cells between cortex and medulla were weakly positive. In 6-month-old chickens, the involuted bursae were negative to the immuno-reaction. Bursae, used as control, treated with preimmune or absorbed serum, showed no immunoreactivity.

\section{Histoenzymatic reactions}

In bursae of 15 day- and 1-month-old chickens, the following was noted:

$L D H$ (Figure 3-a): in the cortex, the cytoplasm of lymphocytes was positive, a few other star-shaped cells were more positive. The cytoplasm of lymphocytes and reticular-epithelial cells in the medulla were uniformally positive, making it difficult to distinguish between them. The epithelial line between cortex and medulla was positive. The cytoplasm of IFE cells had a stronger positivity. In FAE cells of 15-day bursae, the reaction was strong, whereas the reaction in 1-month bursae was weak with a granular appearance.

SDH (Figure 3-b): the cytoplasm of cortical lymphocytes was positive. This positivity was more evident in a few star-shaped cells. In the medulla, the lymphocytes were positive; other cells, probably the epithelial ones, were strongly positive. The epithelial cells between cortex and medulla were positive. The IFE cells, instead, were strongly positive; the FAE cells were weakly positive. 

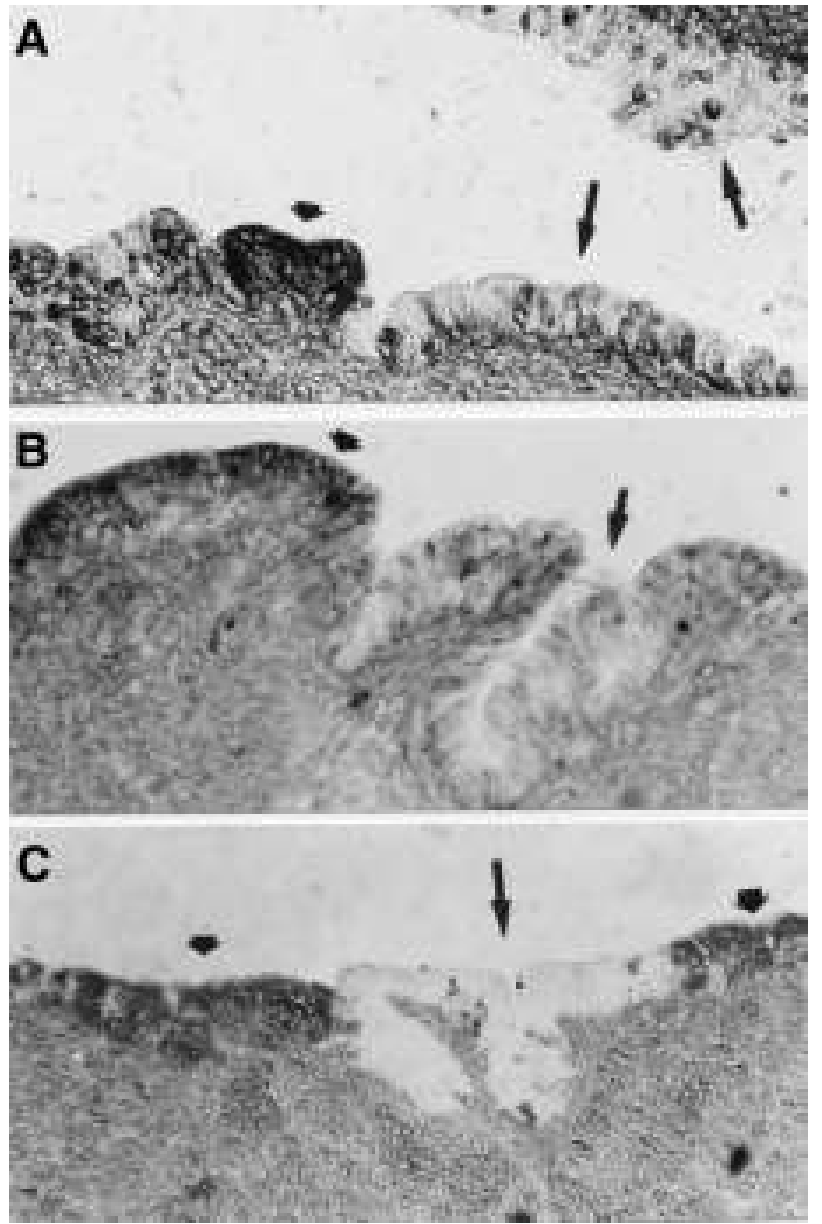

Figure 2. Anti-TS immunoreaction. No counterstain: A, 15 dayold chicken; 25x. B, 1 month-old chicken; 25x. C, 3-month-old chicken. Positivity in FAE cells (thick arrows), IFE is negative (arrows); 6,3x.

NADH: in 15-day bursae, the cytoplasm of cortical and medullary lymphocytes was strongly positive. In 1-month bursae, the cortical lymphocytes showed good positivity, whereas the medullary lymphocytes were weakly positive, rendering the cortical zone more marked than the medullary zone. The cortical-medullary line, and the epithelial cells in the medulla were weakly positive. The reaction was stronger in IFE cells compared to FAE cells.

NADPH: the cytoplasm of cortical and medullary lymphocytes was positive. The epithelial line between cortex and medulla was not well characterized. In the medulla, lymphocytes and stromal cells were uniformly stained. IFE and FAE cells were strongly positive even though in some follicular FAE cells of 1-month-old chickens the reaction was less evident.

$\alpha$-GPDH (Figure 4-a): the cytoplasm of cortical and medullary lymphocytes was weakly positive.

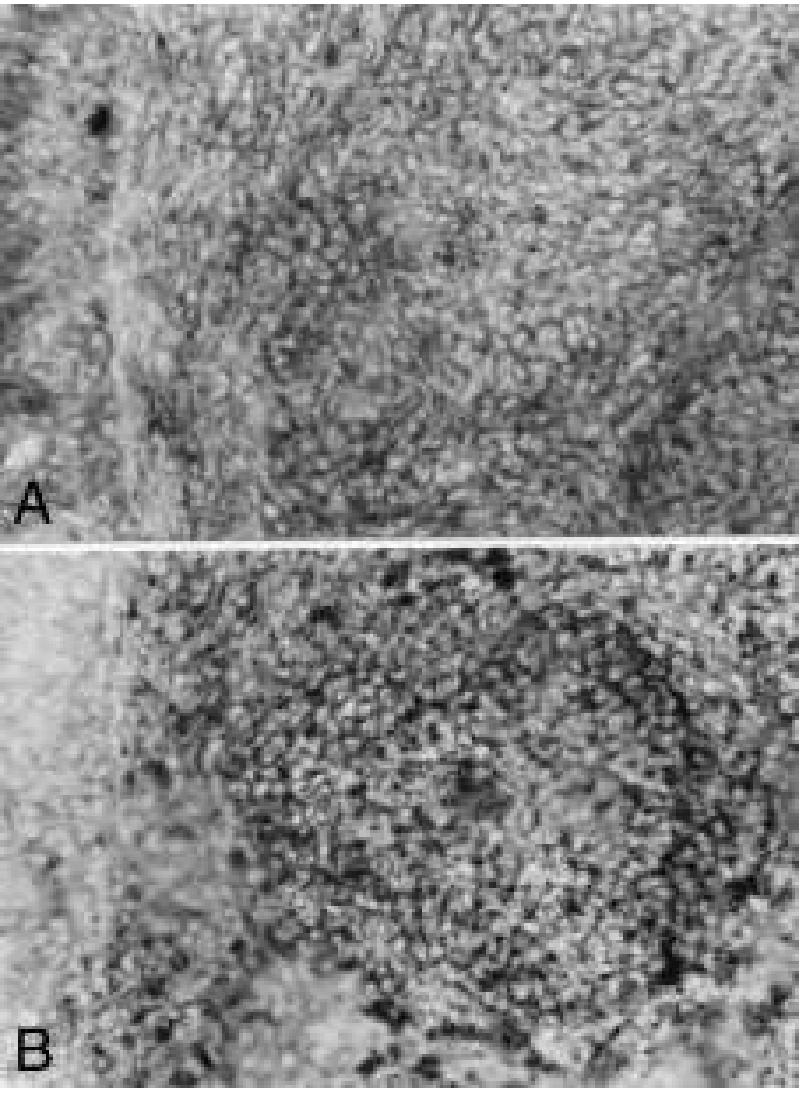

Figure 3. Histoenzymatic reactions in bursa, 15-day-old chicken. A, LDH-cortex: the cytoplasm of lymphocytes is positive; medulla: the cytoplasm of lymphocytes and reticular-epithelial cells is uniformly positive. 40x. B, SDH-positivity in the cytoplasm of cortical lymphocytes and in the epithelial cells between cortex and medulla. Positivity in IFE, weakly positive in FAE. 40x.

The epithelial cells between cortex and medulla were positive. IFE and FAE cells were positive, even though the cells were more accentuated in IFE. In the medulla of some follicles, star-shaped cells were strongly positive.

$\mathrm{Ca}^{++}$-dependent ATP-ase, pH 8.5 (Figure 4-b): cortical, medullary lymphocytes and the epithelium between cortex and medulla were negative. In the medullary zone, the reticular-epithelial cells were strongly positive. IFE and FAE cells were positive. A strong reaction was also localized in the cortical capillaries.

In the bursae of 3-month-old chickens compared to those of 15-day and 1-month-old we noted that:

$\angle D H$ (Figure 5-a): the reaction was the same for IFE and FAE cells and the medullary lymphocytes, whereas the reaction was stronger in cortical lymphocytes and in the epithelial line between cortex and medulla. 

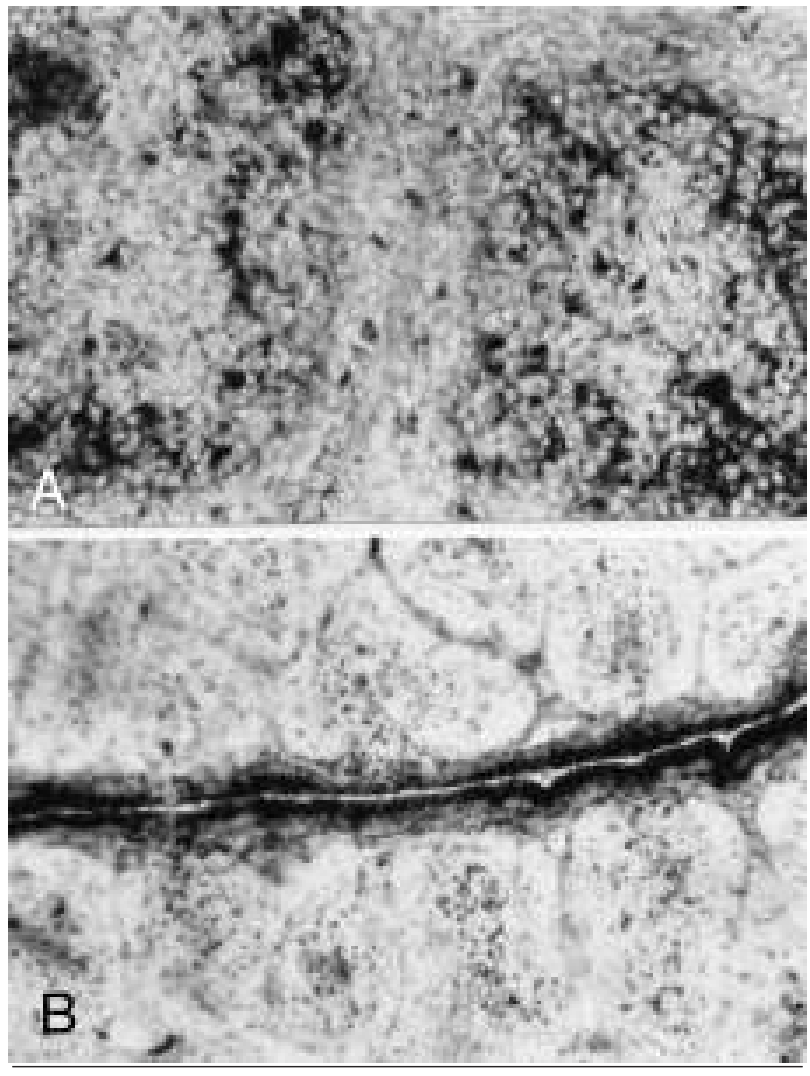

Figure 4. Histoenzymatic reactions in bursa, 15-day-old chicken. a, $\alpha$-GPDH. Positivity in the cytoplasm of cortical and medullary lymphocytes and in the epithelial-line between cortex and medulla. Strong positivity in cortical and medullary epithelial cells. 40x. b, ATP-ase, $\mathrm{pH}$ 8.5. Strong reactivity in IFE, FAE cells and in the medullary epithelial-reticular cells. Positivity in the cortical capillaries. 10x.

$S D H$ (Figure 5-b): this reaction had the same intensity in IFE and FAE cells, whereas it was weaker in cortical and medullary lymphocytes and stronger in the epithelial line between cortex and medulla. Medullary reticular-epithelial cells were less positive than those of cortex.

NADH (Figure 6-a): the reactivity was similar to that of 1-month-old chickens except for the IFE cells where it was less strong.

NADPH (Figure 6-b): every cell of the different zones investigated showed less positivity in comparison to the bursae of younger chickens. IFE cells were strongly reactive.

$\alpha$-GPDH (Figure 7-a, b): no modification was noted in comparison to 15-day- and 1-month-old bursae.

$\mathrm{Ca}^{++}$-dependent ATP-ase $\mathrm{pH}$ 8.5: the reaction of IFE cells was stronger. The epithelium between cortex and medulla showed weak positivity, contrasting with the negativity in younger chickens. Otherwise,
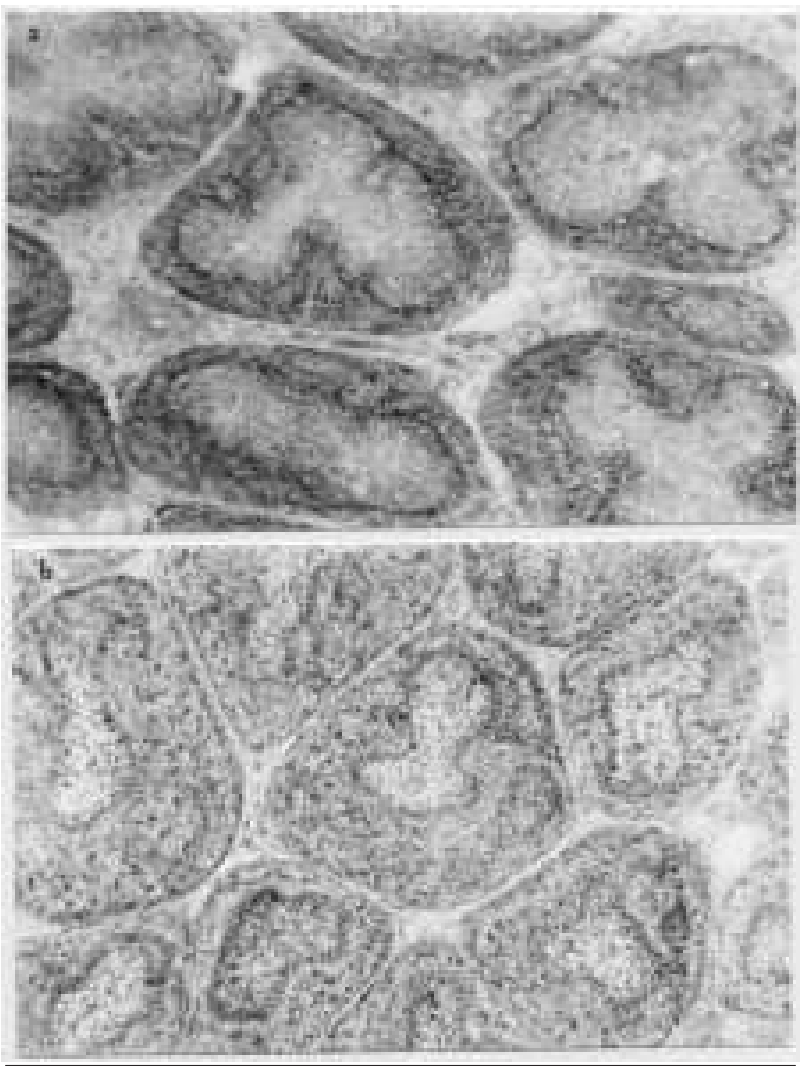

Figure 5. Histoenzymatic reactions in bursa, 3-month-old chicken. a, LDH. Stronger reaction in the cytoplasm of the cortical zone than in that of the medullary zone. Positivity in the epithelial line between cortex and medulla. 25x. b, SDH. High positivity in the epithelial-line between cortex and medulla and in the reticular-epithelial cells. 10x.

the reaction was of the same intensity in every zone.

In the bursae of 6-month-old chickens, we noted that the structure was completely disrupted, and consequently, the reactivities of the enzymes showed changes in the different zones. FAE cells and the cortical-medullary epithelium disappeared (Figure 1-b, c). In the few follicles still present, the cytoplasm of cortical and medullary lymphocytes was positive for LDH, NADH, $\alpha-G P D H$, and weak for SDH, NADPH. Normally, the cortical zone was more reactive than the medullary zone.

In the medulla, the star-shaped cells, probably representing reticular-epithelial cells and macrophages, were strongly positive for a-GPDH and ATP-ase. The cortical-medullary epithelium cells were weakly positive for all enzymes.

Only IFE cells, and the epithelium covering the cysts formed in place of the medulla, showed good reactivity for every enzyme tested (Figure 8 ).

See Table 1 and 2 for a comparative analysis. 

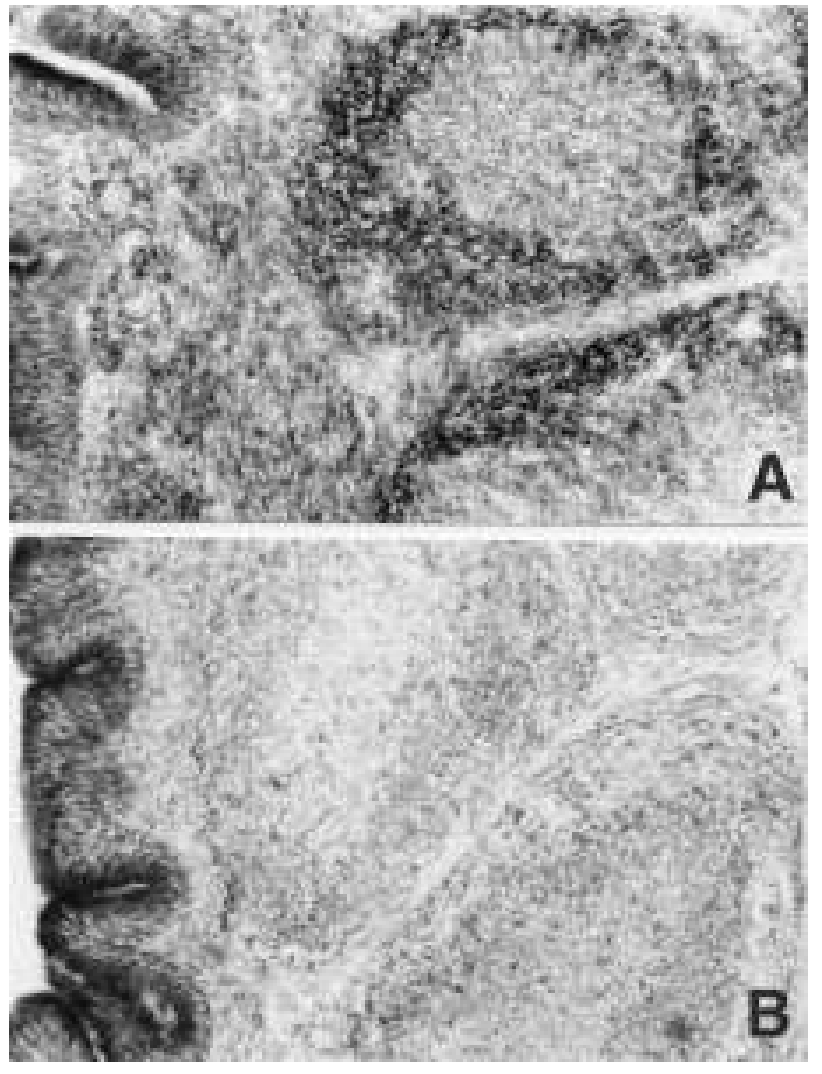

Figure 6. Histoenzymatic reactions in bursa, 3-month-old chicken. A, NADH. High positivity in the cortical lymphocytes and in IFE. B, NADPH. Weak positivity in the cortical zone. High positivity in IFE cells. 25x.

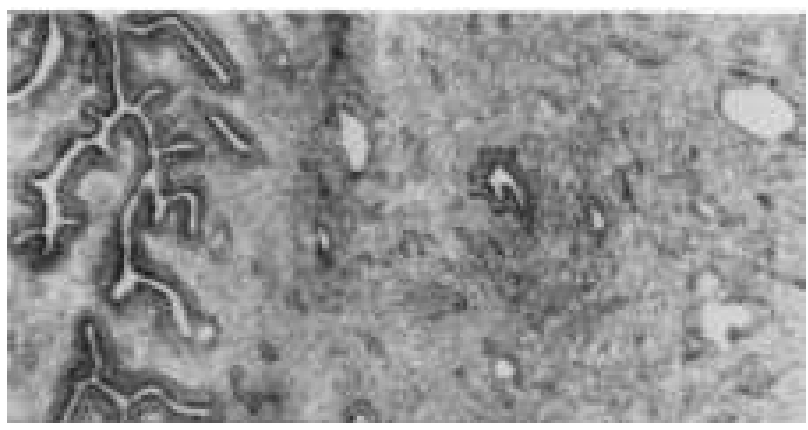

Figure 8. Bursa of 6 month-old chicken. LDH-positivity in IFE cells and in some residual cells of follicles. $25 x$.

\section{Discussion}

The morphological, histochemical, histoenzymatic reactions and immunoreactivity to anti-TS were compared in bursae of aging chickens.

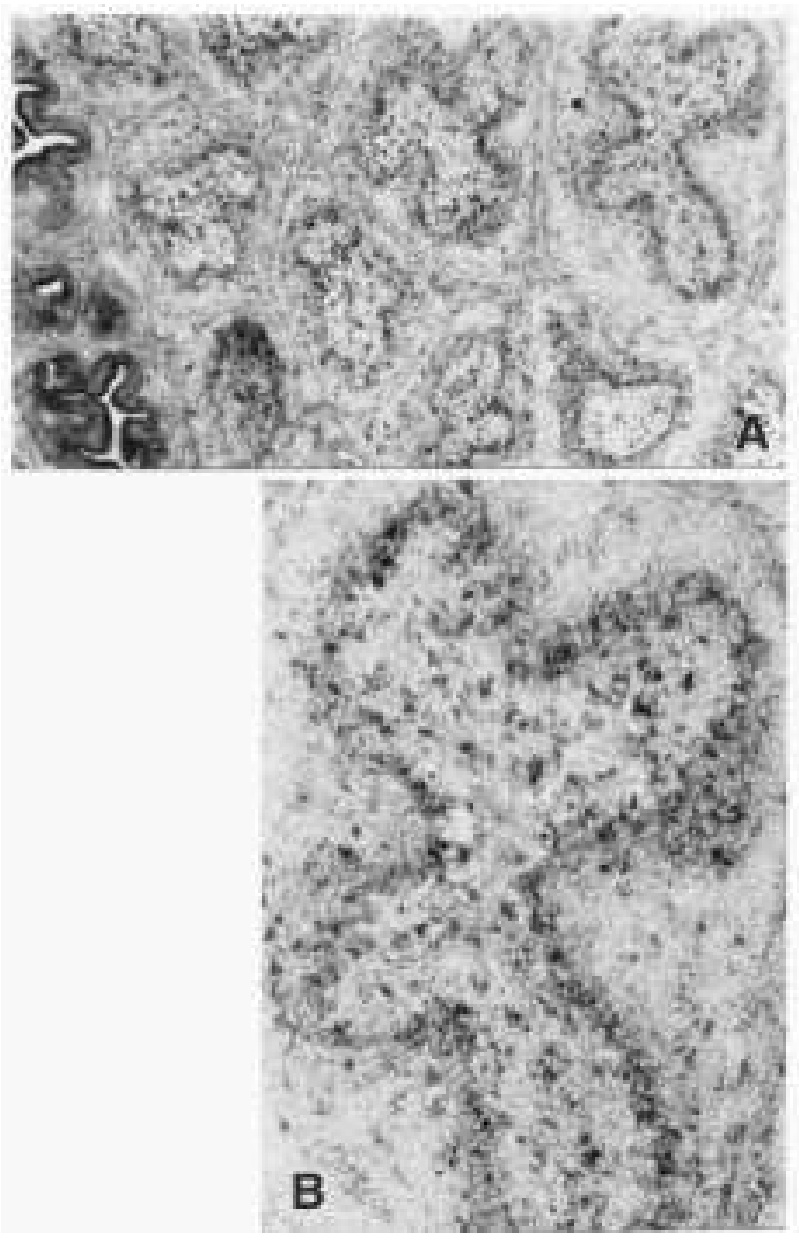

Figure 7. $\alpha$-GPDH histoenzymatic reaction in bursa, 3-month-old chicken. a, strong positivity in the epithelial cells-line between cortex and medulla and in the star-shaped reticular-epithelial cells of medulla. B, higher magnification of ${ }^{*}$ in A. 25x.

\section{Lymphocytes}

We observed that the lymphocytes of cortex and medulla had the same intensity for the histoenzymatic reactions, except for $\mathrm{LDH}$ and $\mathrm{NADH}$. The latter were stronger in cortical lymphocytes of 1and 3-month-old chickens and in the residual follicles of 6-month-old chickens. In contrast with a previous study (Aita et al. 1978) using different buffering and stain concentrations, we found differences in the apparent isoelectric point of proteins in the cytoplasm and nucleus of two types of bursal lymphocytes, presumably staminal cells and mature cells.

\section{Epithelial microenvironment}

In contrast to what was observed for lymphocytes, we found differences in the epithelial microenvironment.

In the cortical zone, PAS, alcian blue and TS reactions were absent in every age examined, 
Table 1. Positivity of cells from follicles microenvironment for the enzyyme activities tested.

\begin{tabular}{|c|c|c|c|c|c|c|c|c|}
\hline \multirow[b]{2}{*}{ Enzyme } & \multicolumn{4}{|c|}{ Cortical-medullary epithelial cells } & \multicolumn{4}{|c|}{ Medullary reticular epithelial cells } \\
\hline & 15 & 1 & 3 & $6^{*}$ & 15 & 1 & 3 & 6 \\
\hline LDH & + & + & ++ & \pm & \pm & \pm & \pm & - \\
\hline SDH & + & + & ++ & \pm & ++ & \pm & \pm & - \\
\hline NADH & \pm & \pm & \pm & \pm & \pm & \pm & \pm & - \\
\hline $\mathrm{NADPH}$ & \pm & \pm & \pm & \pm & \pm & \pm & \pm & - \\
\hline$\alpha-\mathrm{GPDH}$ & \pm & \pm & \pm & \pm & ++ & ++ & + & $++*$ \\
\hline ATPase & - & - & \pm & \pm & ++ & ++ & + & $++*$ \\
\hline
\end{tabular}

15 = 15 days old; $1,3,6$ months old. - = negativity; \pm = weak reactivity; + = positivity; $++=$ strong positivity. ${ }^{*}$ Only in residual follicles.

whereas we found positivity in 15- day, 1- and 3month-old chickens for LDH, SDH and ATP-ase, $\mathrm{pH} 8.5$ in a few star-shaped cells, presumably macrophages. The macrophages, in this zone, have been described ultrastructurally by Frazier (1974). In some follicles of 6-month-old chickens, where the division in cortex and medulla was still visible, rare cortical cells were still positive for these enzymes. Azan-Mallory stain and the ATP-ase reaction pictured vessels only in the cortex and in the collagenous space between cortex and medulla, confirming the absence of vascularization of the medulla (Jolly, 1914; Ackerman and Knouff, 1959). This particular distribution was supposed to constitute a blood-bursa barrier (Davenport and Allen, 1995).

In the medullary zone, different stromal cells were present: the reticular-epithelial cells, also denominated dendritic-reticular cells (Viamontes et al., 1989), the secretory dendritic-like cells and macrophages.

The reticular-epithelial cells detected during embryonic development (Jolly, 1914; Ackerman and Knouff, 1959; Ackerman, 1962; Lupetti et al., 1990) or in adult life (Frazier, 1974; Glick, 1983; Houssaint et al., 1986; Eerola et al., 1987; Boyd et al., 1990; Dolfi et al., 1990; Olah and Glick, 1992) have been described by ultrastructural studies (Frazier, 1974) and classified as pale, dark and intermediate cells. These cells had cytoplasmic processes which were often connected to the adjacent epithelial cells forming a supporting network for the lymphocytes. Other cells in the medulla were free. They could be stained by anti-cytokeratin sera (Viamontes et al., 1989; Dolfi et al., 1990; Lupetti et al., 1990; Olah and Glick, 1992) and detected by
Table 2. Positivity of cells from bursal IFE and FAE for the enzyyme activities tested.

\begin{tabular}{|c|c|c|c|c|c|c|c|c|}
\hline \multirow[b]{2}{*}{ Enzyme } & \multicolumn{4}{|c|}{ IFE } & \multicolumn{4}{|c|}{$F A E$} \\
\hline & 15 & 1 & 3 & $6^{*}$ & 15 & 1 & 3 & 6 \\
\hline LDH & ++ & ++ & ++ & ++ & ++ & \pm & \pm & $\varnothing$ \\
\hline SDH & ++ & ++ & ++ & ++ & \pm & \pm & \pm & $\varnothing$ \\
\hline NADH & ++ & ++ & + & ++ & + & + & + & $\varnothing$ \\
\hline NADPH & ++ & ++ & + & + & ++ & + & \pm & $\varnothing$ \\
\hline$\alpha-G \mathrm{GPH}$ & ++ & ++ & ++ & ++ & ++ & + & \pm & $\varnothing$ \\
\hline ATPase & ++ & + & +++ & ++ & + & + & + & $\varnothing$ \\
\hline
\end{tabular}

specific monoclonal antibodies (Houssaint et al., 1986; Houssaint, 1987; Boyd et al., 1990).

These cells reacted with anti-bursin antibody (Viamontes et al., 1989). The secretory dendriticlike cells have been characterized by electron microscopy as elongated cells with granules in the cytoplasm. They are located in the medulla and at the cortico-medullary border (Olah and Glick, 1981, 1987, 1995; Glick, 1991) and are probably derived from the dark, vimentin-positive mesenchymal cells which migrated beneath the bursal epithelium during embryonic development (Glick, 1994), and the S-100 positive ones, localized within and under the FAE and along the cortico-medullary line (Gallego et al., 1996). These cells express a complete IgG chain and granular products and may act as signals for B-lymphocyte differentiation and gene conversion (Glick and Olah, 1993; Glick, 1995; Paramithiotis and Ratcliffe, 1996). Ciriaco et al. (1994) observed a decrease in the number of these cells during the involutive period (90-120 days) in pigeon bursa.

The macrophages have been described in the medulla using specific markers (Houssaint, 1987) or by electron microscopy (Frazier, 1974; Olah and Glick, 1987).

In our study of the medulla of 15-day-, and 1and 3-month-chickens, the histological stains and histochemical reactions allowed the lymphocytes with a dark nucleus and a pale rim of cytoplasm to be distinguished from other cells with larger and clear cytoplasm, but did not permit the different types of stromal cells to be distinguished. The cytoplasm of some cells of 3-month-old chickens contained acid polysaccharides stained by the alcian blue reaction. Using a histoenzymatic reaction, we 
noted that the medullary stromal cells, without the possibility of distinguishing the type, were more strongly reactive to $\mathrm{SDH}, \alpha-\mathrm{GPDH}$ and ATP-ase at $\mathrm{pH} 8.5$ than to the other enzymes tested. These reactions were present in rare cells of the few follicles not yet regressed of the 6-month-old chickens.

The situation of the partially or totally regressed follicles of 6-month-old chickens was very different. The medulla was devoid of cells and the space was occupied by hyaline material reactive to the PAS and alcian blue reactions. Here the macrophages were very evident, filled with brown material.

\section{Cortico-medullary epithelial line}

This epithelial line, whose basal lamina was continuous with that of the IFE, was positive to antikeratin (Viamontes et al., 1989; Olah and Glick, 1992) and anti-bursin antibodies (Viamontes et al. 1989). During embryogenesis, the epithelial cells, together with the bud formation, expressed $\mathrm{KI}$ antigen, and after hatching, this antigen was restricted to cortico-medullary and FAE cells (Olah et al., 2002).

In this study, we found that these epithelial cells were weakly positive to the anti-TS reaction and strongly positive to $\mathrm{LDH}$ and SDH; they were weakly positive to NADH, NADPH and $\alpha-G P D H$, with very small differences among the ages studied. ATP-ase pH 8.5 was weakly positive only in 3month-old bursa, in contrast to the negativity in younger chickens.

In 6-month-old chickens, there was weak positivity only to every enzyme tested in the remaining follicles.

\section{Plical epithelium}

In chick embryos, the IFE is of epithelial origin and is columnar, constituted mainly by three types of cells: oval, columnar and goblet. The apical part of these cells contained PAS-positive secretory material (Ackerman and Knouff, 1959; Bockman and Cooper, 1973; Betti, 1989). Romano et al. (1996), in ultrastructural studies, have also described an undifferentiated type cell. The IFE was reactive to anti-cytokeratin antibody (Viamontes et al., 1989; Olah and Glick, 1992). The basal layer lining the IFE contained bursin (Viamontes et al., 1989; Otsubo et al., 2001). The origin of FAE cells is controversial. It has been reported that the FAE cells are epithelial cells (Schaffner et al., 1974a; Schaffner et al., 1974b; Davenport and Allen, 1995; Paramithiotis and Ratcliffe, 1996), which are positive (Viamontes et al., 1989), or weakly positive (Olah and Glick, 1992) to anti-cytokeratin antibodies. Other authors reported that they are mesenchymal cells (Dolfi et al., 1981; Lupetti et al., 1983, 1986; Lupetti et al., 1990), that are negative to anti-cytokeratin (Lupetti et al., 1990). Olah et al. (2001) and Nagy et al. (2001) found that the monoclonal antibodies to GIIF3 and NIC2, which are able to recognize mesenchymal elements, were expressed by FAE cells and cortico-medullary cells. FAE cells, similarly to macrophages, were sensitive to silica and carrageenan (Dolfi et al., 1981; Lupetti et al., 1983). Particular matter and bacteria were pinocytosed by these cells from bursal lumen and transported into the medulla (Schaffner et al., 1974a; Schaffner et al., 1974b; Sorvari et al., 1975; Sorvari and Sorvari, 1977; Naukkarinen and Sorvari, 1980; Ekino et al., 1985).

FAE cells were positive to esterase and $\beta$-glucuronidase reactions.

Moderate activity of $\mathrm{N}$-acetyl-glucosaminidase was also present in contrast to high activity of macrophages (Schaffner et al., 1974a). The FAE was negative to anti-bursin antibody (Viamontes et al., 1989). Only FAE-supporting cells were positive (Otsubo et al., 2001).

Through ultrastructural studies, Olah and Glick (1992) noticed that the FAE was supported by 3 to 5 layers of stratified epithelial cells which were a continuation of the cortico-medullary epithelial cells, and was constituted of M cells and scattered secretory dendritic cells. Romano et al., (1996) found that the FAE was organized in multistratified polygonal cells and lacked a basal lamina; underneath these multistratified polygonal cells there were FAE-supporting cells which separated the FAE from the medullary environment. Other cells (FAE-bordering cells) separated the FAE from IFE and medulla. The FAE cells that projected into the lumen possessed microvilli of moderate length.

In our study, we observed that the luminal surface of the plical epithelium was covered by a material that was positive to the PAS and alcian blue reactions. The IFE cells were strongly positive to every enzyme at every age tested. Ali et al. (1996) described positivity to NADPH-diaphorase and to nitric-oxide synthase (NOS) in neuronal cells and in IFE cells of the bursa. The distribution in the IFE cells might suggest that nitric oxide (NO) plays a role in the regulation of the secretory activity of 
this epithelium for mucopolysaccharides. IFE cells were negative to the anti-TS reaction, whereas the basal lamina was weakly positive.

The FAE cells, on the contrary, showed a strong positivity to anti-TS antibody, in 15-day-, 1- and 3month-old chickens. FAE cells, in 1- and 3-monthold chickens, were positive to the enzymes tested but with less intensity with respect to IFE. In 6month-old chickens, FAE cells were no longer present.

The anti-TS reaction localized in the cytoplasm was of the same intensity as that found in bursae of normal (Aita et al. 1992) or partially decerebrated embryos (Mastrolia et al., 1992). To our knowledge, this is the first time that a mammalian thymic factor is clearly visible in the bursa, even if restricted to FAE cells and less evident in the basal lamina of IFE. In a previous study, (Aita et al., 1995) we found also positivity to anti-TS serum in some cystic epithelial cells of the avian thymic medulla. Considering that TS is composed of a family of peptides, it may be concluded that one or more of these peptides is shared by the two lymphatic organs.

In a previous study (Aita et al., 1989b; Manelli, et al., 1989), injecting the anti-TS serum on the 12th day of embryonal incubation, we found, on the 19th day, a moderate reduction in thymic development and a considerable reduction in the number and development of FAE cells, and consequently of the bursal buds together with necrosis of the lymphocytes.

These data confirm the peculiarity of these cells, not only for their conflicting origin, but also for their physiological properties, i.e. pinocytosis of particular matter and bacteria from bursal lumen, negativity for anti-bursin antibody and positivity for anti-TS antibody. These facts support the idea that FAE cells may be essential also for the induction of maturation and differentiation of B-lymphocytes. Eerola et al., (1982) showed that, in vitro, cultured epithelium of chick bursa and its soluble products were able to initiate $B$ cell differentiation with the appearance of surface Ia-like antigens. Unfortunately, through the reading of their Materials and Methods section, we must assume that they used both IFE and FAE epithelia together, without having the possibility of verifying which type was able to initiate this differentiation.

Few literature data are available on the cytoarchitectural changes during physiological bursal regression. Attention was more focused on the bursal weight variations during post-hatching matura- tion (Glick, 1974, 1983; Bellamy and Mohamed, 1982). Glick (1974) reported a medullary lymphocyte loss at 2 months of age in White Leghorn chickens, suggesting a bursal regression. On the other hand, Bellamy and Mohamed (1982) reported an increase of bursal weight throughout the period from 9 to 58 days in Cockerels and Comet strains. Jolly $(1911, b)$ described in part the phenomenon of bursal regression. He observed that, in the chicken, the maximum development was reached at five months, and thereafter there was a slow process of atrophy. The bursa disappeared at nine or ten months. The more salient phenomena were: the gradual disappearance of lymphocytes beginning in the cortex and continuing in the medulla, where in any case, they disappeared completely. The lymphoid tissue was substituted by fibrous tissue, and inside it there were cysts covered by cuboid epithelial cells filled with hyaline substance and leucocytes. Franchini and Ottaviani (1999) observed that in Gallus domesticus, the histological modifications in the bursa appeared at 2 months and that $\beta$-endorphin appeared in the FAE and in dendriticreticular cells between 4 days and 2 months, while ACTH, $\alpha$-MSH and cytokine-like molecules appeared in follicles after 2 months.

The timing of bursal regression probably depends on the strain of chicken (Jolly, 1914) and on the environmental situation (Glick, 1974), and is determined genetically (Bellamy and Mohamed, 1982).

In any event, bursal growth was inversely related to the development of the testes, with the morphological and physiological regression preceding sexual maturity (Bellamy and Mohamed, 1982; Glick, 1983). The bursa was sensitive to adrenal and gonadal steroid hormones which experimentally may cause its regression (Papermaster and Good, 1962; Erickson and Pincus, 1966; Freeman, 1971; Gasc et al., 1979; Le Douarin et al., 1980; Ylikomi et al., 1987; Wilson and Boyd, 1990; Mase and Oishi, 1991), or decrease the number of proliferating cells (Higgins et al., 2002). Research from the laboratory of Garcia-Espinosa et al., (2002) demonstrated the existence of a bursal anti-steroidogenic peptide (BASP) presenting structural homology to histone H1. BASP had an anti-proliferative action on lymphocytes. High doses of testosterone injected in chick embryos blocked the development of bursal endoderm (Le Douarin et al., 1980 ). Gonadectomy changed the bursal structure (Milicevic and Milicevic, 1993). Conversely, the bursa may influ- 
ence gonadal development (Byrd et al., 1993; Civinini et al., 1993; 1994). We observed that in 3month-old chickens, the bursal cytoarchitecture and histochemical reactions were still normal, with only some medullary epithelial cells of a few follicles containing acid polysaccharides being stained by the alcian blue reaction; this is probably the beginning of hyaline secretion that will fill the epithelial-cells-covered cysts of the medullary zone in the degenerated follicles in 6-month-old chickens, in agreement with the description of Jolly $(1911, b)$. On the contrary, in 6-month-old chickens, the process of regression is well evident even if not all follicles are regressed. In the same histological section, it is possible to see a graduality of this phenomenon from still normal follicles to follicles with a thin cortex and medulla, devoid of lymphocytes, and finally to cysts covered with epithelial cells and filled with hyaline substance.

IFE cells are well evident but FAE cells are no longer present. In any event, the fact that, in the few normal follicles, the cortical and medullary lymphocytes and the epithelial compartment still show reactivity to the enzymes tested could support the idea that there is residual physiological activity, even if reduced. Considering that the bursa and thymus are the two primary lymphatic organs in birds committed to immunological functions, humoral and cellular, respectively, it is interesting to compare their different involutionary patterns, even if there is very scarce information in the literature. Bellamy and Mohamed (1982), observing the bursa and the thymus of Comet strain chicks only up to 60 days of age, found that the bursa increased during the first 3 weeks and thereafter underwent regression, whereas the thymus increased throughout the period. Jolly (1914) observed that bursal involution preceded that of the thymus. In our experience (Aita et al., 1995 ) the thymus of 3- and 6 months presented a gradual reduction of the cortical thickness, but was filled with lymphocytes. In the medullary zone, the epithelial clusters were formed by a reduced number of cells but were still well reactive to the enzymes tested. Only the cystic epithelial cells, reacting to anti-TS, were weakly positive in 6 month thymus. Comparing the phenomena of age involution in thymus and bursa, we may conclude that it begins firstly in thymus, in 3month-old chickens and progresses slowly till 6 months, whereas it appears after 3 months in bursa but is more evident and dramatic in 6-month-old chickens.

\section{Acknowledgements}

This research was supported by funds from the Italian Ministero dell'Università e della Ricerca Scientifica e Tecnologica (MURST) to M.A.

\section{References}

Ackermann GA. Electron microscopy of the Bursa of Fabricius of the embryonic chick with particular reference to the lympho-epithelial nodules. J Cell Biol 1962; 13:127-38.

Ackerman A, Knouff R. Lymphocytopoiesis in the Bursa of Fabricius. The Am J Anat 1959; 104:163-205.

Aguila MC, Dees WL, Haensly WE, Mc Cann SM. Evidence that somatostatin is localized and synthetized in lymphoid organs. Proc Natl Acad Sci USA 1991; 88: 11485-89.

Aita M, Amantea A, Lorenzini MC . Studio istochimico degli organi linfatici 2.- Ricerca del punto isoelettrico a livello dei linfociti di timo, borsa di Fabrizio e milza di pollo. Riv Istoch norm pat 1978; XXII: 127-34.

Aita M, Ammirati P, Falchetti R, Pezzella M. Immunological and immunohistochemical properties of an anti-thymostimulin (TPI) serum. Cell Mol Biol 1981; 27:369-75.

Aita M, Cocchia D, Minella AB, Amantea A. Identification of thymostimulin secreting cells in calf thymus by immunoperoxidase method. Histochemistry 1984; 80:207-11.

Aita M, Minella AB, Palermo D. Localization of thymostimulin in mouse and rat thymuses. Basic Appl Histochem 1986; 30:53-9.

Aita M, Minella AB, Palermo D, Gabrielli F, Franzè A. Localization of thymostimulin in mammalian thymuses: comparative evaluation. Cell Mol Biol 1989a; 35:137-45.

Aita M, Brenna S, Mazzone AM. Thymostimulin-like immunoreaction in avian thymus and bursa of Fabricius. Basic Appl Histochem 1989b; 33/suppl. 9.

Aita M, Amantea A. Distribution of anti-keratins and anti-thymostimulin antibodies in normal and in Down's syndrome human thymuses. Thymus 1991; 17:155-65.

Aita M, Mastrolia L. Immunolocalization of thymostimulin in avian thymus and bursa of Fabricius. Gen Comp Endocrinol 1991; 82: 270.

Aita M, Evangelista A, Romano N, Mastrolia L. Identification of thymostimulin-like secreting cells in the chicken embryos' Bursa of Fabricius. In: Wegmann R, Wegmann MA, eds. Recent Adv in Cell Mol Biol, vol.1. Peeters Press, Leuven, 1992, pp. 51-5.

Aita M, Mazzone AM, Gabrielli F, Evangelista A, Brenna S. Identification of cells secreting a thymostimulin-like substance and examination of some histoenzymatic pathways in aging avian primary lymphatic organs: I. Thymus. Eur J Histochem 1995; 39:289300.

Aiuti F, Ammirati P, Fiorilli M, D'Amelio R, Franchi P, Calvani M, Businco L. Immunological and clinical investigation on a bovine thymic extract. Therapeutic applications in primary immunodeficiencies. Pediatr Res 1979; 13: 797-802.

Ali SM, Chan AS, Leong SK. Histochemical and immunohistochemical localization of nitrergic neuronal and non-neuronal cells in the bursa of Fabricius of the chicken. Cell Tissue Res 1996; 285:273-9.

Audhya T, King R, Goldstein G. Bovine probursin tetradecapeptide contains amino acid sequence from somatostatin, tuftsin and bursin. Life Sci 1991; 48:773-80.

Audhya T, Kroon D, Heauner G, Viamontes G, Goldstein G. Tripeptide structure of bursin, a selective B-cell-differentiating hormone of the bursa of Fabricius. Science 1986; 231:997-9.

Back 0, Back R, Hemmingsson EJ, Liden S, Linna TJ. Migration of bone marrow cells to the Bursa of Fabricius and the spleen in the chicken. Scand J Immunol 1973; 2:357-65.

Bellamy D, Mohamed K. A comparative study of age involution of the Bursa of Fabricius and Thymus in birds. Thymus 1982; 4:107-14.

Betti F. Development of the cloacal Bursa in the domestic fowl. I. An allometric and morphological study of the interfollicular surface epithelium (ISE). Anat Anz 1989; 168:337-46. 
Bockman DE, Cooper MD. Pinocytosis by epithelium associated with lymphoid follicles in the Bursa of Fabricius, appendix, Peyer's patches. An electron microscopy study. Am J Anat 1973; 136:465-78.

Boyd RL, Wilson TJ, Ward HA, Mitrangas K. Phenotypic characterization of chicken bursal stromal elements. Devel Immunol 1990; 1: 41-51.

Brand A, Gilmour DG, Goldstein G. Lymphocyte-differentiating hormone of bursa of Fabricius. Science 1976; 193:319-21.

Brand A, Galton J, Gilmour DG. Committed precursors of B and T lymphocytes in chick embryo bursa of Fabricius, thymus and bone marrow. Eur J Immunol 1983; 13:449-55.

Byrd JA, Hayes TK, Wright MS, Dean GE, Hargis BM. Detection and partial characterization of an anti-steroidogenic peptide from the humoral immune system of the chicken. Life Sci 1993; 52:1195207.

Chang TS, Glick B, Winter AR. The significance of the bursa of Fabricius of chickens in antibody production. Poultry Sci 1955; 34: 1187.

Ciriaco E, Laura R, Mammola CL, Vita G, Germana G, Vega JA. Age related changes in the secretory-dendritic cells of the pigeon bursa of Fabricius. An immunohistochemical and ultrastructural study. Annals Anat 1994; 176:571-75.

Civinini A, Petrucci S, Gallo VP. Chick gonadogenesis following early surgical bursectomy. I Histological, morphometric and histochemical data on the embryonic left ovary. Anat Embryol 1993; 187:55764.

Civinini A, Gallo VP, Petrucci S. Chick gonadogenesis following early surgical bursectomy. II Ultrastructural data on the embryonic left and right female gonads. Anat Embryol 1994; 190: 439-44.

Cooper MD, Peterson RDA, South MA, Good RA. The functions of the thymus system and the bursa system in the chicken. J Exp Med 1966; 123:75-101.

Cordier A. L'innervation de la bourse de Fabricius durant I'embryogenèse et la vie adulte. Acta Anat 1969; 73:38-47.

D'Agostaro G, Frasca D, Garavini M, Doria G. Analisys of T and B cell functions in the in vitro antibody response. Restoration of $T$ helper cell activity of ageing mice by injection of thymic factors. Cell Immunol 1980; 53:207-13.

Davenport WD Jr, Allen ER. Evidence for a blood-bursa barrier. Cell Tissue Res 1985; 240:251-53.

Davenport WD Jr, Allen ER. Dome epithelium and follicle-associated basal lamina pores in the avian Bursa of Fabricius. Anat Record 1995; 241:155-62.

Davies EG, Levinsky RJ. Treatment of cell-mediated immunodeficiency with calf thymic hormone (TP1). Pediatric Res 1982; 16:573-8.

Dent PB, Good RA. Absence of antibody production in the Bursa of Fabricius. Nature 1965; 207:491-3.

Di Carlo R, Meli R, Florio S, Mattace Raso G, Gualillo O, Paganini G. The effect of age and sex on the expression of prolactin binding activity in the chicken Bursa of Fabricius. Life Sci $1996 ; 59: 1803$

Dolfi A, Lupetti M., Giannessi F. Toxic effect of carrageenan on lymphoid-follicle associated epithelial cells of the bursa of Fabricius of chickens. Cell Tissue Res 1981; 221:67-75.

Dolfi A, Giannessi F, Bianchi F, Lupetti M. Ultrastructural and immunocytochemical study on bursal follicle medulla cells in Gallus domesticus. Z Mikros Anat Forsch 1990;104:401-11.

Edwards JL, Murphy RC, Cho Y. On the development of the lymphoid follicles of the Bursa of Fabricius. Anat Rec 1975 ; 181:735-54.

Eerola E, Lassila 0, Gilmour DG, Toivanen A. Induction of B cell differentiation in vitro by bursal epithelium. J Immunol 1982; 128: 2652-55.

Eerola $E$, Veromaa $T$, Toivanen P. Special features in the structural organization of the avian lymphoid system. In: Toivanen $\mathrm{P}$, ed. Avian immunology: Basis and Practice. Vol. 1 CRC Press, 1987, pp.10-21.

Ekino S, Suginohara K, Urano T, Fujii H., Matsuno K, Kotani M. The Bursa of Fabricius: a trapping site for environmental antigens. Immunol 1985; 55:405-10.

Erikson $A E$, Pincus G. Modification of embryonic development of reproductive and lymphoid organs in the chick. J Embryol Exp Morph 1966; 16:211-29.

Fabricius Hieronimus ab Aquapendente. De formatione ovi et pulli tractatus accuratissimus. Patavii, 1621.

Falchetti R, Bergesi G, Eshkol A, Cafiero C, Adorini L, Caprino L.
Pharmacological and biological properties of a calf thymus extract (TP1). Drugs Expl Clin Res 1977; 3:39-47.

Falchetti R, Caprino L, Cafiero C. Enhancement of the immunocompetence in neonatal guinea-pigs by a thymic factor (TS). Thymus $1981 ; 2: 215-24$

Falchetti R, Cafiero C, Caprino L. Impaired T-cell functions in aged guinea-pigs restored by thymostimulin (TS). Int $\mathrm{J}$ Immunopharmacol 1982; 4:181-6.

Franchini A, Ottaviani E. Immunoreactive POMC-derived peptides and cytokines in the chicken thymus and bursa of Fabricius microenvironment age-related changes. J Neuroendocrinol 1999; 11:685-92.

Frazier JA. The ultrastructure of the lymphoid follicles of the chick bursa of Fabricius. Acta Anat 1974; 88:385-97.

Freeman BM. The endocrine status of the bursa of Fabricius and the thymus gland. In: Bell J, Freeman BM, eds. Phisiology and Biochemistry of the domestic fowl. Vol.1. Academic Press, 1971. pp. 575-87.

Funk PE, Thompson C.B. Current concepts in chicken B cell development. In:Vaini O, Imhof BA, eds. Immunology and Developmental Biology of the chicken. Springer, Berlin, 1996, pp. 17-28.

Gallego M, Del Cacho E, Felices C, Varas A, Baseuas JA. Distribution of bursal secretory dendritic cells in the chicken. Anat Rec 1996; 246:372-6.

Garcia-Espinosa G, Moore RW, Berghman LR, Hargis AR. Relationship of bursal anti-steroidogenic peptide (BASP) and histone $\mathrm{Hl}$. Life Sci 2002 ; 71:3071-9.

Gasc JM, Sar M, Stumpf WE. Androgen target cells in the Bursa of Fabricius of the chick embryo: autoradiographic localization. Proc Soc Exp Biol Med 1979; 160:55-8.

Glick B. The Bursa of Fabricius and immunoglobulin synthesis. Avian Diseases 1974; 18:345-402.

Glick B. Bursa of Fabricius. In: Farner DS, King JR Parkes KC, eds. Avian Biology. Vol.7. Acad. Press, London, N.Y., 1983, pp. 443-500.

Glick B. Historical perspective: The Bursa of Fabricius and its influence on B-cell development, past and present. Veter Immunol Immunopathol 1991; 80:3-12.

Glick B. The Bursa of Fabricius: the evolution of a discovery. Poultry Sci 1994; 73:979-83.

Glick B. Embryogenesis of the Bursa of Fabricius:stem cell, microenvironment, and receptor-paracrine pathways. Poultry Sci 1995; 74: 419-26.

Glick B, Chang TS, Jaap RG. The bursa of Fabricius and antibody production. Poultry Sci 1956; 35:224-5.

Glick B, Olah I. Bursal secretory dendritic-like cell:a microenvironment issue. Poultry Sci 1993; 72:1262-6.

Glick B, Perkins WD Jr, Rosse C, Schwarz MR. Comparison of lymphocyte populations bearing surface immunoglobulins in avian bone marrow, bursa, spleen, and thymus. Int Archs Allergy appl Immunol $1975 ; 49: 332-40$

Grossi CE, Casali AM, Bartoli S, Governa M, Manzoli FA. Separation and characterization of cortical and medullary bursal lymphocytes. Eur J Immunol 1974; 4:150-2.

Grossi CE, Lydyard PM, Cooper MD. B-cell ontogeny in the chicken. Ann Immunol (Inst. Pasteur) 1976; 127: 31-941.

Higgins SE, Berghman LR, Moore RW, Caldwell D J, Caldwell DY, Tizard I, Hargis BM. In situ detection and quantification of bursa of Fabricius cellular proliferation or apoptosis in normal or steroidtreated neonatal chicks. Poultry Sci 2002; 81:1136-41.

Houssaint E, Diex E, Hallet MM. The bursal microenvironment: phenotype characterization of the epithelial component of the bursa of Fabricius with the use of monoclonal antibodies. Immunol 1986; 58:43-9.

Houssaint E. Cell lineage segregation during bursa of Fabricius ontogeny. J Immunol, 1987; 138: 3626-34.

Jankovic B.D, Isakovic K, Micic M, Knezevic Z. The embryonic lymphoneuro-endocrine relationship. Clin Immunol Immunopathol 1981; 18:108-20.

Jolly J. Histogénèse des follicules de la Bourse de Fabricius. C R Soc Biol 1911a; 1:422-4.

Jolly J. Sur I'involution de la Bourse de Fabricius. C R Soc Biol 1911b; 1:564-7.

Jolly J. La bourse de Fabricius et les organes lympho-epithéliaux. Archs Anat microsc 1914; 16: 363-547. 
Lassila 0. Emigration of B cells from chicken bursa of Fabricius. Eur J Immunol 1989; 19:955-8.

Lechner 0, Dietrich H, Wiegers GJ, Vacchio M., Wick G. Glucocorticoid production in the chicken bursa and thymus. Int Immunol 2001; 13:769-76.

Le Douarin NM, Houssaint E, Jotereau FV, Belo M. Origin of hemopoietic stem cells in embryonic bursa of Fabricius and bone marrow studied through interspecific chimeras. Proc Nat Acad Sci USA 1975; 72:2701-5.

Le Douarin NM, Jotereau FV, Houssaint E, Belo M. Ontogeny of the avian thymus and bursa of Fabricius studied in interspecific chimeras. Ann Immunol (Inst. Pasteur) 1976; 127 C:849-56.

Le Douarin NM, Michel G, Baulieu EE. Studies of testosteroneinduced involution of the bursa of Fabricius. Devel Biol 1980; 75: 288-302.

Le Douarin NM, Dieterlen-Lièvre F, Oliver PD. Ontogeny of primary lymphoid organs and lymphoid stem cells. Am J Anat 1984; 170: 261-99.

Lin $\mathrm{CY}$, Hsu $\mathrm{HC}$, Chen $\mathrm{CL}$, Shen EY. Treatment of combined immunodeficiency with thymic extract ( Thymostimulin ). Ann Allergy 1987; 58:379-84.

Lupetti M., Dolfi A., Giannessi F., Michelucci S. Ultrastructural aspects of the lymphoid follicle-associated cells of the cloacal bursa after treatment with silica or carrageenan. J Anat 1983; 136:85162.

Lupetti M, Dolfi A, Giannessi F, Michelucci S. A contribution to the study of the histogenesis of the bursal lymphoid follicles in Gallus domesticus. Anat Anz Jena 1986; 162:83-92.

Lupetti M, Dolfi A, Giannessi F, Bianchi F, Michelucci S. Reappraisal of histogenesis in the bursal lymphoid follicle of the chicken. Am J Anat 1990; 187:287-302.

Manelli H, Aita M, Mastrolia L. Effects of hypophysectomy or antithymostimulin serum on chick embryo lymphatic organs and gonads. Gen Comp Endocrinology 1989; 74:304.

Mase $Y$, Oishi T. Effects of castration and testosterone treatment on the development and involution of the bursa of Fabricius and the thymus in the japanese quail. Gen Comp Endocrinol 1991; 84: 426-33.

Marsh JA., Scanes CG. Neuroendocrine-immune interactions. Poultry Sci 1994; 73: 1049-61.

Masteller EL, Thompson CB. B cell development in the chicken. Poultry Sci 1994; 73:998-1011.

Masteller EL, Larsen RD, Carison LM, Pickel JM, Nickoloff B, Lowe $J$, Thompson CB, Lee KP. Chicken B cells undergo discrete developmental changes in surface carbohydrate structure that appear to play a role in directing lymphocyte migration during embryogenesis.Development 1995; 121:1657-67.

Mastrolia L, Aita M, Romano N, Gallarello F, Jamele M, Manelli H. Histological study of the primary lymphatic organs in partially decerebrated chicken embryos. Acta Embryol Morphol Experiment 1986; 7:112.

Mastrolia L, Aita M, Romano N, Evangelista A, Manelli F, Manelli H. Effects of hypophyseal grafts on thymus and Bursa of Fabricius in partially decerebrated chick embryos. Acta Embryol Morphol Experiment 1987; 8:419-26.

Mastrolia L, Romano N, Evangelista A, Aita M, Manelli H. Anti-thymostimulin reaction in bursa of Fabricius of partially decerebrated chicken embryos. In: Wegmann R, Wegmann MA, eds. Recent Adv in Cell Mol Biol, vol.1. Peeters Press, Leuven, 1992 pp. 57-62.

Mc Connachie PR, Ruth RF. The epithelium of the Bursa of Fabricius and survival in a natural environment. Folia Biologica 1973; 20:4450.

Milicevic' Z, Milicevic' N. Structure of the Bursa of Fabricius and immune response to Brucella abortus in the chicken after neonatal gonadectomy. Ann Anat 1993; 175:291-8.

Motyka B, Reynolds JD. Apoptosis is associated with the extensive B cell death in the sheep ileal Peyer's patch and the chicken bursa of Fabricius: a possible role in B cell selection. Eur J Immunol 1991; 21:1951-8.

Nachlas M.M, Tsou KC, De Souza E, Cheng CS, Seligman A.M. Cytochemical demonstration of succinic deydrogenase by the use of a new p-nitrophenyl-substituted ditetrazole. J Histoch Cytoch 1957; 5:420-36.

Nagy N, Magyar A, David C, Gumati MK, Olah I. Development of the follicles-associated epithelium and the secretory dendritic cell in the bursa of Fabricius of the guinea fowl (Numida meleagris) studied by novel monoclonal antibodies. Anat Rec 2001; 262:279-92.

Naukkarinen A, Sorvari TE. Cellular transport of colloidal carbon in the follicle-associated epithelium of the chicken bursa of Fabricius. J Reticuloendotelial Soc 1980;28:473-82.

Nowak KJS, Vainio 0, Lassila 0. In vitro organ culture of embryonic Bursa of Fabricius. Dev Comp Immunol 1990; 14:239-46.

Obranovich TD, Boyd RL. A bursal stromal derived cytokine induces proliferation of MHC Class II bearing cells. Dev Comp Immunol 1996; 20:61-75.

Olah I, Glick B. Secretory cells in the medulla of the bursal follicle: the small lymphocyte-like cells are precursors of the secretory cells. Dev Comp Immunol 1981; 5:639-48.

Olah I, Glick B. Bursal secretory cells, an electron microscope study. Anat Record 1987; 219: 268-74.

Olah I, Glick B. Follicle-associated epithelium and medullary epithelial tissue of the Bursa of Fabricius are two different compartments. Anat Record 1992; 233:577-87.

Olah I, Glick B. Dendritic cells in the bursal follicles and germinal centers of the chicken's caecal tonsil express Vimentin but not Desmin. The Anat Record 1995; 243:384-89.

Olah I, Nagy N, David C, Gumati MK, Magyar A. Ontogeny of the dendritic, and follicle-associated epithelial cells in the bursa of Fabricius of guinea fowl (Numida meleagris). Ital J Anat Embryol 2001; 106: 271-7.

Olah I, Gumati KH, Nagy N, Magyar A, Kaspars B, Lillehoj H. Diverse expression of the K1- antigen by cortico-medullary and reticular epithelial cells of the bursa of Fabricius in chicken and guinea fowl. Dev Comp Immunol 2002; 26:481-8.

Otsubo Y, Chen N, Kajiwara E, Horcuchi K, Matsuba H, Furusowa S. Role of bursin in the development of $B$ lymohocytes in chicken embryonic Bursa of Fabricius. Develop Comp Immunol 2001;25: 485-93.

Papermaster BW, Good RA. Relative contributions of the thymus and the Bursa of Fabricius to the maturation of the lymphoreticular system and immunological potential in the chicken. Nature 1962; 196: 838-40.

Paramithiotis $E$, Jacobsen KA, Ratcliffe MJH. Loss of surface immunoglobulin expression precedes $B$ cell death by apoptosis in the Bursa of Fabricius. J Exp Med 1995; 181:105-13.

Paramithiotis $E$, Ratcliffe MJH. Bursa-dependent subpopulations of peripheral B lymphocytes in chicken blood. Eur J Immunol 1993 ; 23:96-102.

Paramithiotis E, Ratcliffe MJH. B cell emigration directly from the cortex of lymphoid follicles in the bursa of Fabricius. Eur J Immunol $1994 a ; 24: 458-63$.

Paramithiotis E, Ratcliffe MJH. Survivors of bursal B cell production and emigration. Poultry Sci 1994b; 73: 991-7.

Paramithiotis $\mathrm{E}$, Ratcliffe MJH. Evidence for phenotypic heterogeneity among $B$ cells emigrating from the Bursa of Fabricius, a reflection of functional diversity ?. In: Vainio 0 , Imhof BA, eds. Immunol and Develop Biol of the chicken, Springer Berlin, 1996, pp 29-36.

Pearse AGE. Histochemistry. Theoretical and applied, vol 2. Churchill Livingstone, Edinburgh and London, 1972.

Peterson R.D.A, Good RA. Morphologic and developmental differences between the cells of the chicken's thymus and bursa of Fabricius. Blood 1965; 26:269-79.

Petrini M, Bianchi F, Dolfi A, Lupetti M. Distribution of the 1,25 dihydroxy-vitamin D3 receptor in the bursa of Fabricius of chicken. Experientia 1991; 47: 838-41.

Pink JR, Vainio 0, Rijnbeek AM. Clones of B lymphocytes in individual follicles of the bursa of Fabricius. Eur J Immunol 1985; 15:83-7.

Reynaud C., Weill JC. A few comments about the Cohn and Langman theory of the ontogeny of the chicken humoral immune system. 52nd Forum in Immunology. Res Immunol 1993; 144: 464-6.

Ritter M.A, Lebacq AM. Embryonic bursa development in vitro. Eur J Immunol $1977 ; 7: 468-75$.

Romano N, Baldassini MR, Abelli L, Aita M, Mastrolia L. Ultrastructural study on the plical epithelium of the bursa of Fabricius in chick embryos: influence of partial decerebration and hypophyseal allografts. J Anat 1996; 188: 29-41.

Scanes CG, Duyka DR, Lauterio TJ, Bowen SJ, Huybrechts LM, Bacon WL. King DB. Effect of chicken growth hormone, triiodothyronine and hypophysectomy in growing domestic fowl. Growth 1986; 50: 12-31. 


\section{A.M. Mazzone et al.}

Scarpelli DG, Hess R, Pearse AGE. The cytyochemical localization of oxidative enzymes. I .Diphospho pyridine nucleotide diaphorase and triphosphopyridine nucleotide diaphorase. J Biophys Biochem Cytol 1958; 4:747-60.

Schaffner T, Mueller J, Hess MW, Cottier H, Sordat B, Ropke C. The Bursa of Fabricius: a central organ providing for contact between the lymphoid system and intestinal content. Cell Immunol 1974a; 13: 304-12.

Schaffner T, Hess M.W., Cottier $H$. A reappraisal of bursal functions. Ser Haemat 1974b; VII: 568-92.

Shoam J, Eshe I. Thymic hormonal effect on human peripheral blood lymphocytes in vitro. III Conditions for mixed lymphocyte tumor culture assay. J Immunol Methods 1980; 7: 261-73.

Shoam J, Cohen M, Chandali Y, Avni A. Thymic hormonal activity on human peripheral lymphocytes in vitro. I Reciprocal effect on $T$ and $B$ rosette formation. Immunology 1980; 41: 353-59.

Sorvari T, Sorvari R, Ruotsalainen P, Toivanen A, Toivanen P. Uptake of environmental antigens by the bursa of Fabricius. Nature 1975 ; 253: 217-9.

Sorvari R, Sorvari TE. Bursa Fabricii as a peripheral lymphoid organ. Transport of various materials from the anal lips to the bursal lymphoid follicles with reference to its immunological importance. Immunology 1977; 32: 499-505.

St. Pierre RL, Ackerman GA. Bursa of Fabricius in chickens: possible humoral factor. Science 1965; 147: 1307-8.

Sternberger LA, Hardy PH Jr, Cuculis JJ, Meyer HG. The unlabeled antibody enzyme method of immunohistochemistry. Preparation and properties of soluble antigen-antibody complex (horseradish peroxidase-antihorseradish peroxidase) and its use in identification of spirochetes. J Histoch Cytoch 1970; 18:315-35.

Toivanen P, Toivanen A, Linna TJ, Good RA. Ontogeny of bursal functions in chicken II. Postembryonic stem cell for humoral immunity. The J Immunol 1972a; 109: 1071-80.
Toivanen P, Toivanen A, Linna TJ, Good RA. Ontogeny of bursal functions in chicken. III-Immunocompetent cell for humoral immunity. The J Exp Med 1972b; 136: 816-31.

Toivanen P, Toivanen A, Tamminen P. Bursal and postbursal cells in chicken. Separation by gradient centrifugation. Eur J Immunol $1974 ; 4: 220-3$

Touraine JL, Sanhadji K. Effect of factors from thymic epithelial cells on human bone marrow cells in vitro and clinical application to the treatment of Di George syndrome. In:Wegmann R, Wegmann MA eds. Recent advances in Cell Mol Biol, vol.1, Peeters Press, Leuven, 1992,pp. 25-33.

Verne J, Wegmann R, Tordet-Caridot C, Hebert S. La mise en evidence de I'acide lactique et de la lactico-dehydrogenase dans les cultures de tissues. Ann Histochem 1961; 5: 41-5.

Viamontes GI, Audhya TK, Babu V, Goldstein G. Immunohistochemical localization of bursin in epithelial cells of the avian bursa of Fabricius. The J Histoch Cytoch 1989; 37:793-9.

Wegmann R, Bankowsky Z. Differenciation histochimique de 4 groupes d'adenosine triphosphatases selon Slater. Ann Histochim 1960; 5: 121-41.

Wilson TJ, Boyd RL. Cyclophosphamide-and testosterone-induced alteration in chicken bursal stroma identified by monoclonal antibodies. Immunology 1990; 70:241-6.

Woods R, Linna J. The transport of cells from the bursa of Fabricius to the spleen and the thymus. Acta Path Microbiol, Scandinav 1965; 64: 470-6

Ylikomi T, Gasc JM, Tuohimaa P, Baulieu EE. Ontogeny of oestrogensensitive mesenchymal cells in the bursa of Fabricius of the chick embryo. An immunohistochemical study on progesterone receptor. Development 1987; 101: 61-6. 